Original Article

\title{
Arthropod fauna on the abaxial and adaxial surfaces of Acacia mangium (Fabaceae) leaves
}

\author{
Fauna de artrópodes nas superfícies abaxial e adaxial de folhas de Acacia mangium \\ (Fabaceae)
}

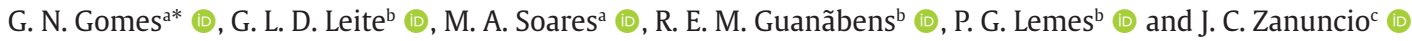 \\ aUniversidade Federal dos Vales do Jequitinhonha e Mucuri - UFVJM, Departamento de Agronomia, Programa de Pós-graduação em Produção \\ Vegetal, Diamantina, MG, Brasil \\ bUniversidade Federal de Minas Gerais - UFMG, Instituto de Ciências Agrárias - ICA, Montes Claros, MG, Brasil \\ 'Universidade Federal de Viçosa - UFV, Departamento de Entomologia/BIOAGRO, Viçosa, MG, Brasil
}

\begin{abstract}
Acacia mangium (Willd., 1806) (Fabales: Fabaceae) is a fast growing, rustic, pioneer species, with potential to fix nitrogen, and for programs to recover degraded areas. The objective was to evaluate the distribution and the functional diversity of interactions and the K-dominance of arthropod groups on A. mangium saplings. The number of individuals of eleven species of phytophagous insects, three bee species, and fourteen natural enemy species were highest on the adaxial leaf surface of this plant. Abundance, diversity and species richness of phytophagous insects and natural enemies, and abundance and species richness of pollinators were highest on the adaxial A. mangium leaf surface. The distribution of five species of sap-sucking hemipterans and six of protocooperating ants (Hymenoptera), with positive interaction between these groups, and three bee species (Hymenoptera) were aggregated on leaves of $A$. mangium saplings. Aethalion reticulatum (L.) (Hemiptera: Aethalionidae) and Bemisia sp. (Hemiptera: Aleyrodidae); Brachymyrmex sp. and Camponotus sp. (Hymenoptera: Formicidae); and Trigona spinipes Fabricius (Hymenoptera: Apidae) were the most dominant phytophagous insects, natural enemies, and pollinators, respectively, on A. mangium leaves. Knowledge of preferred leaf surfaces could help integrated pest management programs.
\end{abstract}

Keywords: aggregation, distribution, diversity, insect, K-dominance, spiders.

\begin{abstract}
Resumo
Acacia mangium (Willd., 1806) (Fabales: Fabaceae) é uma planta pioneira com rápido crescimento, rusticidade, potencial nitrificador e importante em programas de recuperação de áreas degradadas. $\mathrm{O}$ objetivo foi avaliar a distribuição e a diversidade funcional das interações e a dominância-K de grupos de artrópodes em árvores jovens de A. mangium. Os números de indivíduos de onze espécies de insetos fitófagos, três de abelhas e quatorze de inimigos naturais foram maiores na superfície adaxial de folhas dessa planta. A abundância, diversidade e riqueza de espécies de insetos fitófagos e inimigos naturais, e a abundância e riqueza de espécies de polinizadores foram maiores na face adaxial de folhas de A. mangium. A distribuição de cinco espécies de hemípteros sugadores de seiva e seis de formigas protocooperantes (Hymenoptera), com interação positiva entre esses grupos, e três de abelhas (Hymenoptera) foi agregada em folhas de plantas jovens de A. mangium. Aethalion reticulatum (L.) (Hemiptera: Aethalionidae) e Bemisia sp. (Hemiptera: Aleyrodidae); Brachymyrmex sp. e Camponotus sp. (Hymenoptera: Formicidae); e Trigona spinipes Fabricius (Hymenoptera: Apidae) foram os insetos fitófagos, inimigos naturais e polinizadores mais dominantes, respectivamente, em folhas de A. mangium. A definição da superfície foliar preferida pode auxiliar programas de manejo integrado de pragas.
\end{abstract}

Palavras-chave: agregação, distribuição, diversidade, insetos, dominância-K, aranhas.

\section{Introduction}

Acacia mangium (Willd.,1806) (Fabales: Fabaceae) is a fast growing, rustic pioneer species with potential for nitrification and high litter production (Caldeira et al., 2018; Eloy et al., 2018). The high nitrogen fixation rate of this plant, in symbiosis with diazotrophic bacteria, increases the production of biomass and nutrients through litter, favoring plant succession (Paula et al., 2018). The high adaptability of $A$. mangium to acidic and infertile soils makes this plant important for recovering degraded areas (Balieiro et al., 2005; Wang et al., 2013). Acacia mangium

*e-mail: gleisyanny@gmail.com

Received: November 12, 2020 - Accepted: May 14, 2021

This is an Open Access article distributed under the terms of the Creative Commons Attribution License, which permits unrestricted use, distribution, and reproduction in any medium, provided the original work is properly cited. 
wood is used in the construction of furniture, cabinets, frames, doors and window components, boxes and crates and in the production of coal, coal briquettes and activated carbon (Hegde et al., 2013). The sap-sucking insect Aethalion reticulatum (L., 1767)(Hemiptera: Aethalionidae); the defoliating insects Periphoba hircia (Cramer, 1775) (Lepidoptera: Saturniidae), and Tropidacris collaris (Stoll, 1813) (Orthoptera: Romaleidae); the stem apex chewing insect Trigona spinipes (Fabr., 1793) (Hymenoptera: Apidae); and the wood-borer insect Oncideres ocularis (Thomson, 1868) (Coleoptera: Cerambycidae) damage A. mangium trees (Lemes et al., 2013; Parreira et al., 2014; Silva et al., 2015, 2020).

Herbivorous insects can damage different plant parts, including their leaves (adaxial and abaxial surfaces) (Leite et al., 2008). Sap-sucking insects prefer the abaxial leaf surface due to its softer tissue, thin epidermis and more protuberant veins (Leite et al., 2008; Damascena et al., 2017). In addition, they are better protected against natural enemies and climatic factors (e.g., solar radiation) on this leaf surface (Leite et al., 2008). On the other hand, arthropods, such as defoliating Coleoptera and Orthoptera may prefer the adaxial leaf surface where less effort is required for movement (Salerno et al., 2018). The preference of insect pests for this leaf surface helps in their control (Leite et al., 2008), which becomes more difficult in the case of pests that live and feed on the abaxial leaf surface (Naranjo and Flint, 1995).

The distribution of herbivorous insects and of their natural enemies can be completely randomized (i); in groups, such as aggregated or contagious (ii); or evenly spread with uniform - regular (iii) distributions on the host plants or on the ground (Nickele et al., 2010). Knowledge of insect distribution is important for sampling plans and pest management (Nickele et al., 2010; Soti et al., 2018; Fernandes et al., 2019). The number of insect species per location is usually high with few dominant species (Monteiro et al., 2019). K-dominance indicates the distribution and uniformity of individuals between species and facilitates the identification of potential pests (Gee et al., 1985).

Functional diversity includes different physical, biochemical, behavioral and phenological characteristics, which are measurable (Cadotte et al., 2011). These characteristics are called functional because they are important for understanding how species richness and diversity are related to the ecosystem (Cadotte et al. 2009; Flynn et al. 2011), determining when and where they may exist and their interspecific interactions (e.g., predator and prey) (McGill et al., 2006). For this reason, measuring and understanding species characteristics helps in decisionmaking in restoration and environmental conservation programs (Cadotte et al., 2011).

The terms "hypotheses" and "predictions" are confused in studies of ecology. The hypothesis is an idea that can be verified by examining the predictions, which result from the assumption that the first is true (Farji-Brener, 2004). Therefore, the objective of this research was to test the following hypotheses: i) the number of phytophagous insects and pollinators and their natural enemies or protocooperating ants will be higher on the adaxial leaf surface due to the lower effort required for movement, therefore resulting in higher ecological indices (abundance, diversity, and species richness) of these groups; ii) the distribution of arthropods will be aggregated on the same host sapling, mainly of sap-sucking and protocooperating insects (e.g., ants, eusocial insects), protecting them against competitors and predators; and iii) the k-dominance of polyphagous insect pests or omnivorous insects (e.g., ants) will be greater on $A$. mangium saplings (younger trees).

\section{Material and Methods}

\subsection{Experimental site}

This study was carried out in a degraded area $(\approx 1$ ha) of the "Instituto de Ciências Agrárias da Universidade Federal de Minas Gerais (ICA/UFMG)" in the municipality of Montes Claros, Minas Gerais state, Brazil (latitude $16^{\circ} 51^{\prime} 38^{\prime \prime} \mathrm{S}$, longitude $44^{\circ} 55^{\prime} 00^{\prime \prime} \mathrm{W}$, altitude $943 \mathrm{~m}$ ) for 24 months (April 2015 to March 2017). The climate of this area, according to the Köppen climate classification (Alvares et al., 2013), is tropical dry, with annual precipitation and temperature between 1,000 and $1,300 \mathrm{~mm}$ and $\geq 18{ }^{\circ} \mathrm{C}$, respectively. The soil is Neosol Litolic with an Alic horizon (Silva et al., 2020).

\subsection{Experimental design}

The $A$. mangium seedlings were prepared, in March 2014 , in a nursery in plastic bags $(16 \times 24 \mathrm{~cm})$ with reactive natural phosphate mixed with the substrate at a dosage of $160 \mathrm{~g}$ and planted, at the same time, in the final site in September of this year. Each $A$. mangium seedling was planted in a hole $(40 \times 40 \times 40 \mathrm{~cm})$ when they were $30 \mathrm{~cm}$ high with a 2-meter spacing between each one. The soil was corrected with dolomitic limestone with the base saturation increased to $50 \%$, natural phosphate, gypsum, FTE (Fried Trace Elements), potassium chloride and micronutrients based on the soil analysis. A total of $20 \mathrm{~L}$ of dehydrated sewage sludge with its biochemical characteristics defined (Silva et al. 2020) was placed in a single dose, per hole. The young $A$. mangium trees (saplings in the vegetative period) were irrigated twice a week until the beginning of the rainy season (October). The design was completely randomized with 48 replications (one sapling each) with the adaxial and abaxial leaf surfaces as the treatments.

\subsection{Counting the arthropods}

The number of leaves/branch, branches/sapling and height ( $\mathrm{m}$ ) of $A$. mangium were $\approx 23,34$, and 34 and 59 , 1,6 , and 2,8 in the first and second years, respectively (unpublished data). All insects (e.g., Formicidae - eusocial insects) and spiders were counted, between 7:00 A.M. and 11:00 A.M., by visual observation, every two weeks on the adaxial and abaxial surfaces of the first 12 leaves expanded, per sapling. These leaves were assessed, randomly, on branches (one leaf per position) in the basal, middle and apical parts of the canopy - vertical axis - (0 to $33 \%, 33$ to $66 \%$ and 66 to $100 \%$ of total sapling 
height, respectively) and in the north, south, east and west directions - horizontal axis. A total of 12 leaves/sapling/ evaluation were observed on 48 A. mangium saplings starting six months after transplantion during 24 months (27,648 total leaves), covering the entire sapling (vertical and horizontal axis), capturing the highest possible number of arthropods (insects and spiders), especially the rarest ones. The evaluator approached, carefully, firstly assessing the adaxial leaf surface and, if it was not possible to visualize the abaxial one, with a delicate and slow movement, lifting the leaf to visualize it. The position of leaves of $A$. mangium saplings is, in general, tilted upwards, facilitating the visual assessment of arthropods on their leaf surfaces. Insects with greater mobility (e.g., Orthoptera), that flew, on approach, were counted as long as they were recognized (e.g., Order). The arthropods (insects and spiders) were not removed from the saplings during the evaluation.

A few arthropod specimens (up to 3 individuals) per species were collected using an aspirator (two hours per week), at the beginning of the study (between transplantation and first evaluation, six months after), stored in flasks with $70 \%$ alcohol, separated into morphospecies, and sent to specialists for identification (see acknowledgments). Any visible arthropod, not yet computed in previous evaluations, was collected, coded and sent to a taxonomist of its group.

\subsection{Statistical ecological indices}

Each replication is the total of individuals collected on 12 leaves (three heights and four sides of the sapling). The distribution of arthropods was defined by the Chisquare test using the BioDiversity® Professional software, Version 2 (Krebs, 1998). The ecological indices (abundance, diversity and species richness) were calculated per group (phytophagous insects, pollinators, and natural enemies) and treatments (adaxial and abaxial surfaces) using the aforementioned program. Abundance and species richness were the total number of individuals and species (Begon et al., 2007), respectively, per sapling. The diversity was calculated using Hill’s formula per sapling (Hill, 1973).

The data for abundance, diversity and species richness of phytophagous insects, pollinators and natural enemies were subjected to a non-parametric statistical hypothesis, the Wilcoxon signed rank test ( $p$-value $<0.05$ ) (Wilcoxon, 1945) using the Statistics and Genetics Analysis (SAEG) program, version 9.1 (UFV, 2007) (Supplier: “Universidade Federal de Viçosa", Brazil). The data were subjected to second-degree regression or principal component regression $(P C R)$, when linear ( $p$-value $<0.05$ ) to verify the possible interactions (e.g. protocooperation) between groups of arthropods (phytophagous insects, pollinators and natural enemies, including spiders). Simple equations were selected based on the criteria: i) distribution of the data in the figures (linear or quadratic response), ii) the parameters used in these regressions were the most significant ones (p-value $<0.05$ ), iii) p-value $<0.05$ and $F$ of the Analysis of Variance of these regressions, and iv) the determination coefficient of these equations $\left(R^{2}\right)$. The PCR model uses principal component analysis, based on a covariance matrix, to obtain the regression. These reduce the dimensions of the regression, excluding those that contribute to collinearity, that is, linear relations between the independent variables (Bair et al., 2006). The parameters used in these equations were all significant ( $p$-value $<0.05$ ) according to the selection of the variables by the "Stepwise" method using the statistical program mentioned.

K-dominance was calculated by plotting the cumulative percentage of abundance according to the logarithmic classification of the species (Lambshead et al., 1983), using the aforementioned BioDiversity program. The K-dominance values indicate the distribution of dominance and the uniformity of the number of individuals between species (Gee et al., 1985).

The data presented in the text were the significant ones ( $p$-value $<0.05$ ) and the remaining are in the supplementary material I (used to calculate the ecological indexes).

\section{Results}

A total of 2,497 arthropods were collected on A. mangium leaves, $24.69 \%$ of which were phytophagous (> Hemiptera: $16.61 \%$ ), $66.38 \%$ of natural enemies ( $>49.74 \%$ of ants Hymenoptera) and $8.93 \%$ of pollinating bees ( $>5.73 \%$ of T. spinipes Hymenoptera). The numbers of individuals of eleven phytophagous insect species, three bee species, and fourteen natural enemy species, were highest ( $p$-value < 0.05 ) on the adaxial leaf surface. The abundance, diversity and species richness of phytophagous insects and of natural enemies, and abundance and species richness of pollinators ( $\mathrm{p}$-value $<0.05$ ) were highest on the adaxial A. mangium leaf surface (Tables 1 and 2 ).

The distributions of five sap-sucking hemipterans, six protocooperating ant species (Hymenoptera) and three bee species (Hymenoptera) were the most abundant ones and aggregated on leaves of $A$. mangium saplings (Table 1). The number of Araneidae (Araneae) correlated, positively, with those of Cerotoma sp. (Coleoptera: Chrysomelidae), total Orthoptera, Tropidacris collaris (Stoll, 1813) (Orthoptera: Romaleidae) and Trigona spinipes (Fabr., 1793) (Hymenoptera: Apidae); Oxyopidae (Araneae) with Tetragonisca angustula (Latreille, 1811) (Hymenoptera: Apidae); Aethalium reticulatum (L., 1767) (Hemiptera: Aethalionidae) with Pseudomyrmex termitarius (Smith, 1855) (Hymenoptera: Formicidae); and P. termitarius with Balclutha hebe (Kirkaldy, 1906) (Hemiptera: Cicadellidae) and $A$. reticulatum. The number of Sternorrhyncha predators, Dolichopodidae, T. collaris, and T. angustula was lower on the A. mangium leaves with high numbers of protocooperating ants and those of T. angustula and spiders lower on the A. mangium leaves with high numbers of $T$. spinipes and phytophagous Hemiptera (Table 3).

The K-dominance ( $\mathrm{k}$ ) and total numbers $(\mathrm{n})$ of A. reticulatum individuals were higher on the adaxial ( $k=34.9$ and $n=156$, respectively) leaf surface while those of Bemisia sp. (Hemiptera: Aleyrodidae) were higher on the abaxial ( $k=41.5$ and $n=71$, respectively) leaf surface. Brachymyrmex sp. and Camponotus sp. (Hymenoptera: Formicidae) were the most dominant natural enemies on the adaxial ( $\mathrm{k}=20.8$ and $\mathrm{n}=363$, respectively $)$, and abaxial 
Table 1. Number of arthropods and their aggregated (Aggr.) or random (Ran.) distributions (Dist.) on the adaxial and abaxial leaf surfaces of Acacia mangium (Fabales: Fabaceae)/sapling (mean $\pm \mathrm{SE}$ ).

\begin{tabular}{|c|c|c|c|}
\hline \multirow{2}{*}{ Arthropods } & \multicolumn{2}{|c|}{ Leaf surface* } & \multirow{2}{*}{$\frac{\text { QT }^{* *}}{\text { Dist. }}$} \\
\hline & Adaxial & Abaxial & \\
\hline Araneae: Araneidae & $1.63 \pm 0.28$ & $0.38 \pm 0.11$ & Aggr. \\
\hline Oxyopidae & $1.00 \pm 0.19$ & $0.25 \pm 0.09$ & Aggr. \\
\hline Salticidae & $1.08 \pm 0.24$ & $0.54 \pm 0.22$ & Aggr. \\
\hline Coleoptera: Chrysomelidae, Stereoma anchoralis Lacord. & $0.58 \pm 0.22$ & $0.08 \pm 0.05$ & --- \\
\hline Curculionidae & $0.13 \pm 0.06$ & $0.00 \pm 0.00$ & --- \\
\hline Lampyridae, Photinus sp. & $0.17 \pm 0.09$ & $0.00 \pm 0.00$ & Ran. \\
\hline Diptera: Dolichopodidae & $5.17 \pm 0.52$ & $0.17 \pm 0.07$ & Aggr. \\
\hline Syrphidae, Syrphus sp. & $0.33 \pm 0.13$ & $0.00 \pm 0.00$ & --- \\
\hline Otittidae, Euxesta sp. & $0.75 \pm 0.16$ & $0.00 \pm 0.00$ & --- \\
\hline Hemiptera: Aethalionidae, Aethalium reticulatum L. & $6.50 \pm 4.4$ & $0.04 \pm 0.04$ & Aggr. \\
\hline Cicadellidae, Balclutha hebe Kirkaldy & $0.92 \pm 0.10$ & $0.17 \pm 0.09$ & --- \\
\hline Erythrogonia sexguttata Fabricius & $0.33 \pm 0.13$ & $0.00 \pm 0.00$ & --- \\
\hline Membracidae & $1.13 \pm 0.38$ & $0.08 \pm 0.05$ & Aggr. \\
\hline Nogodinidae & $0.17 \pm 0.09$ & $0.00 \pm 0.00$ & Ran. \\
\hline Bladina sp. & $0.17 \pm 0.07$ & $0.00 \pm 0.00$ & --- \\
\hline Pseudococcidae, Phenacoccus sp. & $0.00 \pm 0.00$ & $2.63 \pm 1.22$ & Aggr. \\
\hline Hymenoptera: Apidae, Apis mellifera L. & $0.71 \pm 0.20$ & $0.17 \pm 0.13$ & Aggr. \\
\hline Tetragonisca angustula Latreille & $2.42 \pm 0.35$ & $0.04 \pm 0.04$ & Aggr. \\
\hline Trigona spinipes Fabricius & $5.58 \pm 1.30$ & $0.38 \pm 0.17$ & Aggr. \\
\hline Formicidae, Brachymyrmex sp. & $15.13 \pm 6.08$ & $0.00 \pm 0.00$ & Aggr. \\
\hline Camponotus sp. & $13.08 \pm 1.91$ & $1.21 \pm 0.32$ & Aggr. \\
\hline Cephalotes sp. & $4.00 \pm 1.99$ & $0.08 \pm 0.05$ & Aggr. \\
\hline Ectatoma sp. & $1.83 \pm 0.37$ & $0.04 \pm 0.04$ & Aggr. \\
\hline Pheidole sp. & $9.50 \pm 1.03$ & $0.71 \pm 0.25$ & Aggr. \\
\hline Pseudomyrmex termitarius Smith & $5.63 \pm 0.81$ & $0.54 \pm 0.21$ & Aggr. \\
\hline Vespidae, Polybia sp. & $4.33 \pm 2.70$ & $0.08 \pm 0.05$ & Aggr. \\
\hline Mantodea: Mantidae, Mantis religiosa L. & $0.21 \pm 0.08$ & $0.04 \pm 0.04$ & --- \\
\hline Orthoptera:Romaleidae, Tropidacris collaris Stoll. & $2.13 \pm 0.28$ & $0.08 \pm 0.05$ & Aggr. \\
\hline Tettigoniidae & $1.67 \pm 0.25$ & $0.08 \pm 0.05$ & Aggr. \\
\hline
\end{tabular}

*WT = Wilcoxon test; ${ }^{* *} \mathrm{QT}=$ Chi-square test; $\mathrm{n}=48$ per treatment; --- $\mathrm{p}$-value $>0.05$, and the remaining are significant.

( $\mathrm{k}=21.0$ and $\mathrm{n}=29$, respectively) leaf surfaces, respectively and $T$. spinipes was the dominant pollinator insect on the adaxial $(\mathrm{k}=64.1$ and $\mathrm{n}=134)$ and $\operatorname{abaxial}(\mathrm{k}=64.3$ and $\mathrm{n}=9)$ leaf surfaces of $A$. mangium leaves.

\section{Discussion}

The greater number, in aggregate pattern, especially of sap-sucking hemipterans (i.e., A. reticulatum) and their protocooperating ants (i.e., P. termitarius), and the three bee species (i.e., T. spinipes) on the adaxial leaf surface of $A$. mangium saplings increased the ecological indices (abundance, diversity and species richness) of these groups (i.e. phytophagous insects) on this leaf surface of A. mangium saplings. This is, probably, due to the lower effort required by these arthropods to hold onto this surface compared to the abaxial one, confirming the first hypothesis (preference for the adaxial leaf surface). The wax content, hairiness, roughness, regular shape or not and the type and number of veins in the leaves of host plants affect arthropod walking and they prefer the leaf surface (adaxial or abaxial) requiring lower effort for movement (Peeters, 2002; Gorb et al., 2008; Gorb and Gorb, 2009; Prüm et al., 2012; Salerno et al., 2018). Acacia mangium leaves are large (11-27 cm long × 3-10 cm wide), hairless, smooth and present four main longitudinal ribs (Hegde et al., 2013) 
Table 2. Abundance, diversity and species richness of phytophagous insects, pollinators, and natural enemies on the adaxial and abaxial leaf surfaces of Acacia mangium (Fabales: Fabaceae)/sapling (mean $\pm \mathrm{SE}$ ).

\begin{tabular}{|c|c|c|c|c|}
\hline & \multicolumn{2}{|c|}{ Leaf surface } & \multicolumn{2}{|c|}{$\mathbf{W T}^{*}$} \\
\hline & Adaxial & Abaxial & $T V E$ & $\boldsymbol{P}$ \\
\hline Abundance of Phytopagous & $24.21 \pm 5.18$ & $7.58 \pm 2.21$ & 4.2 & 0.00 \\
\hline Diversity of Phytopagous & $17.02 \pm 2.14$ & $4.18 \pm 0.81$ & 3.8 & 0.00 \\
\hline Species Richness of Phytopagous & $8.25 \pm 0.55$ & $2.29 \pm 0.33$ & 5.4 & 0.00 \\
\hline Abundance of Polinators & $8.71 \pm 1.38$ & $0.58 \pm 0.21$ & 5.2 & 0.00 \\
\hline Diversity of Polinators & $1.44 \pm 0.44$ & $0.58 \pm 0.19$ & 0.7 & 0.25 \\
\hline Species Richness of Polinators & $2.08 \pm 0.16$ & $0.38 \pm 0.11$ & 5.3 & 0.00 \\
\hline Abundance of Natural Enemies & $63.88 \pm 7.33$ & $5.17 \pm 0.70$ & 5.7 & 0.00 \\
\hline Diversity of Natural Enemies & $18.36 \pm 1.43$ & $6.85 \pm 0.84$ & 4.9 & 0.00 \\
\hline Species Richness of Natural Enemies & $9.71 \pm 0.49$ & $3.13 \pm 0.30$ & 5.6 & 0.00 \\
\hline
\end{tabular}

${ }^{*} \mathrm{WT}=$ Wilcoxon test; $\mathrm{n}=48$ per treatment; ${ }^{\mathrm{E}} \mathrm{TV}=$ Teste value.

Table 3. Relationships between the numbers of Aethalium reticulatum, Araneidae, Balclutha hebe, Cerotoma sp. (Cer.), Dolichopodidae, Orthoptera, Oxyopidae, phytophagous Hemiptera (Hemiptera), protocooperating ants (Ants), Pseudomyrmex termitarius (Pter.), spiders, Sternorrhyncha predators, Tetragonisca angustula (Tangu.), Trigona spinipes (T. spi.), and Tropidacris collaris (T. collaris) on Acacia mangium (Fabales: Fabaceae)/sapling.

\begin{tabular}{|c|c|c|c|}
\hline \multirow{2}{*}{ Principal component regression equations } & \multicolumn{3}{|c|}{ ANOVA } \\
\hline & $\mathbf{R}^{2}$ & $\boldsymbol{F}$ & $\boldsymbol{P}$ \\
\hline Spiders $=1.74+0.66 \times$ Orthoptera $-0.04 \times$ Hemiptera & 0.38 & 13.50 & 0.00 \\
\hline Araneidae $=0.33+0.95 \times$ Cer $+0.28 \times$ T. collaris $+0.07 \times$ T.spi & 0.44 & 11.63 & 0.00 \\
\hline Oxyopidae $=0.27+0.29 \times$ Tetragonisca angusta & 0.34 & 23.42 & 0.00 \\
\hline Aethalium reticulatum $=-2.50+1.87 \mathrm{x}$ Pseudomyrmex termitarius & 0.22 & 13.02 & 0.00 \\
\hline Pter.= $1.76+1.80 \times$ Balclutha hebe +0.11 x Aethalium reticulatum & 0.30 & 9.69 & 0.00 \\
\hline \multicolumn{4}{|l|}{ Second degree regression equations } \\
\hline Sternorrhyncha predators $=0.49+0.19 \times$ Ants $-0.001 \times$ Ants $^{2}$ & 0.60 & 33.74 & 0.00 \\
\hline Dolichopodidae $=-0.03+0.17 \mathrm{x}$ Ants $-0.001 \mathrm{x}$ Ants $^{2}$ & 0.73 & 62.09 & 0.00 \\
\hline Tropidacris collaris $=-0.01+0.06 \times$ Ants $-0.0003 \times$ Ants $^{2}$ & 0.60 & 33.37 & 0.00 \\
\hline Tetragonisca angustula $=-0.09+0.07 \times$ Ants $-0.003 \times$ Ants $^{2}$ & 0.63 & 37.97 & 0.00 \\
\hline Tetragonisca angustula $=0.56+0.37 \times$ Tspi. $-0.01 \times$ Tspi. $^{2}$ & 0.28 & 8.78 & 0.00 \\
\hline
\end{tabular}

$\mathrm{n}=96$.

and probably with a surface that provides restrict contact for arthropods to hold onto, which may have affected the number of these organisms on the adaxial leaf surface.

The aggregate distribution of five species of sapsucking hemipterans, six protocooperating ant species (Hymenoptera) and three bee species (Hymenoptera) on $A$. mangium sapling leaves confirms the second hypothesis (distribution will be aggregated) as found for A. reticulatum and Camponotus sp. on Bauhinia forficata (Link, 1821) (Fabales: Fabaceae), Acrididae (Orthoptera) on several plants, Bemisia tabaci (Genn., 1889) (Hemiptera: Aleyrodidae) on Capsicum annuum (L., 1753) (Solanales: Solanaceae), Dendroctonus ponderosae (Hopkins, 1902) (Coleoptera: Curculionidae) on pine and T. spinipes on cucurbits (Bashir and Hassanali, 2010; Serra and Campos,
2010; Barônio et al., 2012; Goodsman et al., 2016; Kim et al., 2017). This behavior can increase the local population density of arthropods (Rivault et al., 1998; Le Goff et al., 2009), thus facilitating feeding and mating, attraction of mutualistic species, and protection against predators; however, it can also result in conflicts (e.g., competition) between them (Le Goff et al., 2009; Boulay et al., 2019). The positive correlation between spiders and phytophagous insects on A. mangium saplings is, probably, due to the predators following their prey, as observed on Caryocar brasiliense (Cambess., 1828) (Malpighiales: Caryocaraceae), Leucaena leucocephala (Lam.) de Wit (1961) (Fabales: Fabaceae) and Pistacia lentiscus (L., 1753) (Sapindales: Anacardiaceae) (Auslander et al., 2003; Damascena et al., 2017; Leite et al., 2017). The increase in the number of 
phytophagous insects (e.g., Cerotoma sp.) and pollinators (e.g., T. spinipes) allows higher numbers of spiders (e.g., Araneidae) on $A$. mangium saplings because the latter prey on insects in natural and agricultural systems (Venturino et al., 2008; Leite et al., 2012, 2016). On the other hand, the reduction in the number of spider individuals with the increase in that of sap-sucking insects is, possibly, due to interactions between protocooperating ants (e.g., P. termitarius) with these Hemiptera (e.g., A. reticulatum) on A. mangium saplings. Trophobiotic interactions between ants (protecting against natural enemies) and Sternorryncha (supplying sugary food substances) are one of the main mechanisms that maintain the overabundance of ants in ecosystems (Kaminski et al., 2010; Silva and Fernandes, 2016; Klimes et al., 2018), which may decrease that of natural enemies, including spiders (Venturino et al., 2008; Leite et al., 2012, 2016). The reduction in populations of Sternorrhyncha predators (e.g., Dolichopodidae) on $A$. mangium saplings by protocooperating ants shows the negative impact of the latter on the biological control of sap-sucking hemipterans (Karami-Jamour et al., 2018; Tong et al., 2019). The reduction in the number of $T$. angustula by $T$. spinipes indicate possible competition for food and space as observed for sap-sucking insects (e.g., aphids) with chewing insects (e.g., beetles), Eurytoma sp. (Hymenoptera: Eurytomidae) with three other galling hymenopterans on leaves of $C$. brasiliense (Leite et al., 2009, 2012, 2017) and T. spinipes with Apis mellifera (L., 1758) (Hymenoptera: Apidae) and T. angustula on cucurbits and A. mangium (Serra and Campos, 2010; Silva et al., 2020). Phylogenetic proximity tends to favor the formation and maintenance of groups of mixed species (eusocial or gregarious), possibly, due to similar size, life cycle and movement with easier communication between them (Boulay et al., 2019). However, it can increase competition between species that share similar ecological niches (Boulay et al., 2019). The balance between resource sharing and competition is important to understand species clusters, as well as for those occupying the same ecological niche presenting lower food availability or productive partners (Boulay et al., 2019). Interspecific competition can disproportionately benefit one species at the expense of another when arthropods use mixtures of chemical compounds, such as hydrocarbons, to communicate between them (Boulay et al., 2019).

The higher K-dominance and number of the phytophagous Hemiptera A. reticulatum and Bemisia sp., of the natural enemies Brachymyrmex sp. and Camponotus sp. and of the pollinator T. spinipes can be explained by the first two being pests in different cultures (polyphages) which may be feeding and reproducing on A. mangium saplings, confirming the third hypothesis (k-dominance of polyphagous pest insects or omnivorous insects will be greatest). The others are protocooperating sap-sucking insects, such as $A$. reticulatum, a pest that reduces the development of fruits and sprouts, leading to hypertrophy and cracks in the apex of seedlings and possibly killing plants of Erythrina speciosa (Andrews, 1806) (Fabales: Fabaceae) (Araújo et al., 2010; Zanuncio et al., 2015) in addition to damaging those of A. mangium, Triplaris americana (L., 1759) (Caryophyllales: Polygonaceae) and Vernonia condensata
(Baker, 1875) (Asterales: Asteraceae) (Menezes et al., 2013; Pires et al., 2014; Silva et al., 2020). The whitefly B. tabaci transmits viruses to agricultural plants such as Cucumis melo (L., 1753) (Cucurbitales: Cucurbitaceae) (Felicio et al., 2019). Sap-sucking insects, especially at high densities, can be associated with ants of the genera Camponotus and Brachymyrmex with mutual benefit with direct correlation between these groups (Novgorodova, 2015; Sanchez et al., 2020) because they collectively and aggressively defend their resources (e.g., sap-sucking insects) (Novgorodova, 2015). The greater numbers of Brachymyrmex sp., Camponotus sp., and T. spinipes agrees with reports for these insects on L. leucocephala trees, which may be due to attraction by extrafloral nectaries in the leaf petioles of this plant (Damascena et al., 2017), and on $A$. mangium, with an extrafloral nectary on the leaf base (Hegde et al., 2013). The high numbers of $T$. spinipes is a common feature because this insect was reported in this condition on A. mangium, Brassica oleracea var. italica (Plank, 1794) (Brassicales: Brassicaceae), L. leucocephala and Vaccinium sp. (Ericales: Ericaceae) (Silveira et al., 2010; Dos Santos et al., 2012; Damascena et al., 2017; Silva et al., 2020). This insect removes fiber from buds and growth parts to build its nests and reduces pollination (e.g., Cucurbitaceae) because it does not carry pollen and frequently dislodges it from the plant (Serra and Campos, 2010). Bees associated with flowers obtain most of their food resources (e.g., nectar and pollen), but some of their interactions (e.g., T. spinipes) with sap-sucking insects (e.g., A. reticulatum) are an alternative to obtain honeydew as food (Dos Santos et al., 2019).

\section{Conclusions}

The higher values of ecological indices (e.g., abundance) of arthropods (e.g., phytophagous) on the adaxial $A$. mangium leaf surface is probably due to the reduced effort (e.g., easier walking) for insect on this surface compared to the abaxial one. Protocooperating ants, the most dominant natural enemies on $A$. mangium leaves, can reduce the growth of this plant because they are associated with sap-sucking insects and chase away natural enemies like spiders. The greater K-dominance of $A$. reticulatum and $T$. spinipes on A. mangium leaves may be a problem, because these insects can damage leaves and sprouts of this plant. The aggregation behavior of arthropods on the adaxial leaf surface of $A$. mangium favors the control of potential pests of this plant.

\section{Acknowledgements}

We wish to thank the taxonomists Dr. Antônio Domingos Brescovit (Butantan Institute, São Paulo state, Brazil - Arachnida), Dr. Ayr de Moura Bello (Oswaldo Cruz Foundation, Rio de Janeiro state, Brazil - Coleoptera), Dr. Carlos Matrangolo (University of Montes Claros, Minas Gerais state, Brazil - Formicidae), Dr. Ivan Cardoso Nascimento (EMBRAPA-ILHÉUS Cocoa Research Center, CEPLAC, Itabuna, Bahia state, Brazil - Formicidae), Dr. Luci 
Boa Nova Coelho (Federal University of Rio de Janeiro, Rio de Janeiro state, Brazil - Cicadellidae) and Dr. Paulo Sérgio Fiuza Ferreira (Federal University of Viçosa, Minas Gerais state, Brazil - Hemiptera) for the identification of specimens. The voucher numbers are 1595/02 and 1597/02 (CDZOO, Federal University of Paraná, Paraná state, Brazil). The study was financially supported by the Brazilian agencies "Conselho Nacional de Desenvolvimento Científico e Tecnológico (CNPq)", "Fundação de Amparo à Pesquisa do Estado de Minas Gerais (FAPEMIG)", and "Programa Cooperativo sobre Proteção Florestal (PROTEF) do Instituto de Pesquisas e Estudos Florestais (IPEF)".

\section{References}

ALVARES, C.A., STAPE, J.L., SENTELHAS, P.C., GONÇALVES, J.L.M. and SPAROVEK, G., 2013. Köppen's climate classification map for Brazil. Meteorologische Zeitschrift, vol. 22, no. 6, pp. 711-728. http://dx.doi.org/10.1127/0941-2948/2013/0507.

ARAÚJO, V.A., BÁO, S.N., MOREIRA, J., NEVES, C.A. and LINO-NETO, J., 2010. Ultrastructural characterization of the spermatozoa of Aethalion reticulatum Linnaeus 1767 (Hemiptera: Auchenorrhyncha: Aethalionidae). Micron, vol. 41, no. 4, pp. 306-311. http://dx.doi.org/10.1016/j.micron.2009.12.001. PMid:20047835.

AUSLANDER, M., NEVO, E. and INBAR, M., 2003. The effects of slope orientation on plant growth, developmental instability and susceptibility to herbivores. Journal of Arid Environments, vol. 55, no. 3, pp. 405-416. http://dx.doi.org/10.1016/S01401963(02)00281-1.

BAIR, E., HASTIE, T., PAUL, D. and TIBSHIRANI, R., 2006. Prediction by supervised principal components. Journal of the American Statistical Association, vol. 101, no. 473, pp. 119-137. http:// dx.doi.org/10.1198/016214505000000628.

BALIEIRO, F.C., DIAS, L.E., FRANCO, A.A., CAMPELLO, E.F.C. and FARIA, S.M., 2005. Acúmulo de nutrientes na parte aérea, na serapilheira acumulada sobre o solo e decomposição de filódios de Acacia mangium Willd. Ciência Florestal, vol. 14, no. 1, pp. 59-65. http://dx.doi.org/10.5902/198050981781.

BARÔNIO, G., PIRES, A.C.V. and AOKI, C., 2012. Trigona branneri (Hymenoptera: Apidae) as a collector of honeydew from Aethalion reticulatum (Hemiptera: Aethalionidae) on Bauhinia forficata (Fabaceae: Caesalpinoideae) in a Brazilian Savanna. Sociobiology, vol. 59, no. 2, pp. 407-414. http://dx.doi. org/10.13102/sociobiology.v59i2.603.

BASHIR, M.O. and HASSANALI, A., 2010. Novel cross-stage solitarising effect of gregarious-phase adult desert locust (Schistocerca gregaria (Forskål)) pheromone on hoppers. Journal of Insect Physiology, vol. 56, no. 6, pp. 640-645. http://dx.doi.org/10.1016/j. jinsphys.2010.01.012.

BEGON, M., TOWNSEND, C.R. and HARPER, J.L., 2007. Ecologia: de indivíduos a ecossistemas. 4th ed. Porto Alegre: Artmed

BOULAY, J., AUBERNON, C., RUXTON, G.D., HÉDOUIN, V., DENEUBOURG, J.-L. and CHARABIDZÉ, D., 2019. Mixed-species aggregations in arthropods. Insect Science, vol. 26, no. 1, pp. 2-19. http://dx.doi.org/10.1111/1744-7917.12502. PMid:28657138.

CADOTTE, M.W., CARSCADDEN, K. and MIROTCHNICK, N., 2011. Beyond species: functional diversity and the maintenance of ecological processes and services. Journal of Applied Ecology, vol. 48, no. 5, pp. 1079-1087. http://dx.doi.org/10.1111/j.13652664.2011.02048.x.
CADOTTE, M.W., CAVENDER-BARES, J., TILMAN, D. and OAKLEY, T.H., 2009. Using phylogenetic, functional and trait diversity to understand patterns of plant community productivity. PLoS One, vol. 4, no. 5, pp. e5695. http://dx.doi.org/10. 1371/journal. pone.0005695.

CALDEIRA, M.V.W., FAVALESSA, M., DELARMELINA, W.M., GONÇALVES, E.O.G. and MOURA, R.R.S., 2018. Sewage sludge assessment on growth of Acacia mangium seedlings by principal components analysis and orthogonal contrasts. Journal of Plant Nutrition, vol. 41, no. 10, pp. 1303-1311. http://dx.doi.org/10.1 080/01904167.2018.1450421.

DAMASCENA, J.G., LEITE, G.L.D., SILVA, F.W.S., SOARES, M.A., GUANABENS, R.E.M., SAMPAIO, R.A. and ZANUNCIO, J.C., 2017. Spatial distribution of phytophagous insects, natural enemies, and pollinators on Leucaena leucocephala (Fabaceae) trees in the Cerrado. The Florida Entomologist, vol. 100, no. 3, pp. 558565. http://dx.doi.org/10.1653/024. 100.0311.

ELOY, E., SILVA, D.A., CARON, B.O., ELLI, E.F. and SCHWERZ, F., 2018. Effect of age and spacing on biomass production in forest plantations. Revista Árvore, vol. 42, no. 2, pp. 1-11. http://dx.doi. org/10.1590/1806-90882018000200014.

FARJI-BRENER, A.G., 2004. ¿Son hipótesis las hipótesis estadísticas? Ecología Austral, vol. 14, no. 2, pp. 201-203.

FELICIO, T.N.P., COSTA, T.L., SARMENTO, R.A., RAMOS, R.S., PEREIRA, P.S., SILVA, R.S. and PICANÇO, M.C., 2019. Surrounding vegetation, climatic elements, and predators affect the spatial dynamics of Bemisia tabaci (Hemiptera: Aleyrodidae) in commercial melon fields. Journal of Economic Entomology, vol. 112, no. 6, pp. 27742781. http://dx.doi.org/10.1093/jee/toz181. PMid:31265728.

FERNANDES, M.G., COSTA, E.N., CAVADA, L.H., MOTA, T.A. and FONSECA, P.R.B., 2019. Spatial distribution and sampling plan of the phytophagous stink bug complex in different soybean production systems. Journal of Applied Entomology, vol. 143, no. 3, pp. 236-249. http://dx.doi.org/10.1111/jen.12584.

FLYNN, D.F.B., MIROTCHNICK, N., JAIN, M., PALMER, M.I. and NAEEM, S., 2011. Functional and phylogenetic diversity as predictors of biodiversity-ecosystem funciton relationships. Ecology, vol. 92, no. 8, pp. 1573-1581. http://dx.doi.org/10.1890/10-1245.1. PMid:21905424.

GEE, J.M., WARWICK, R.M., SCHAANNING, M., BERGE, J.A. and AMBROSE JUNIOR, W.G., 1985. Effects of organic enrichment on meiofaunal abundance and community structure in sublittoral soft sediments. Journal of Experimental Marine Biology and Ecology, vol. 91, no. 3, pp. 247-262. http://dx.doi. org/10.1016/0022-0981(85)90179-0.

GOODSMAN, D.W., KOCH, D., WHITEHOUSE, C., EVENDEN, M.L., COOKE, B.J. and LEWIS, M.A., 2016. Aggregation and a strong allee effect in a cooperative outbreak insect. Ecological Applications, vol. 26, no. 8, pp. 2623-2634. http://dx.doi.org/10.1002/eap.1404. PMid:27862568.

GORB, E. and GORB, S., 2009. Effects of surface topography and chemistry of Rumex obtusifolius leaves on the attachment of the beetle Gastrophysa viridula. Entomologia Experimentalis et Applicata, vol. 130, no. 3, pp. 222-228. http://dx.doi. org/10.1111/j.1570-7458.2008.00806.x.

GORB, E., VOIGT, D., EIGENBRODE, S.D. and GORB, S., 2008. Attachment force of the beetle Cryptolaemus montrouzieri (Coleoptera, Coccinellidae) on leaflet surfaces of mutants of the pea Pisum sativum (Fabaceae) with regular and reduced wax coverage. Arthropod-Plant Interactions, vol. 2, no. 4, pp. 247-259. http://dx.doi.org/10.1007/s11829-008-9049-0.

HEGDE, M., PALANISAMY, K. and YI, J.S., 2013. Acacia mangium Willd.: a fast growing tree for tropical plantation. Journal of 
Forest and Environmental Science, vol. 29, no. 1, pp. 1-14. http:// dx.doi.org/10.7747/JFS.2013.29.1.1.

HILL, M.O., 1973. Diversity and evenness: a unifying notation and its consequences. Ecology, vol. 54, no. 2, pp. 427-432. http:// dx.doi.org/10.2307/1934352.

KAMINSKI, L.A., FREITAS, A.V.L. and OLIVEIRA, P.S., 2010. Interaction between mutualisms: ant-tended butterflies exploit enemy-free space provided by ant-treehopper associations. American Naturalist, vol. 176, no. 3, pp. 321-334. http:// dx.doi. org/10.1086/655427. PMid:20645858.

KARAMI-JAMOUR, T., MIRMOAYEDI, A., ZAMANI, A. and KHAJEHZADEH, Y., 2018. The impact of ant attendance on protecting Aphis gossypii against two aphidophagous predators and it's role on the intraguild predation between them.Journal of Insect Behavior, vol. 31, no. 2, pp. 222-239. http://dx.doi. org/10.1007/s10905-018-9670-4.

KIM, S., JUNG, M., SONG, Y.J., KANG, C., KIM, B.Y., CHOI, I.J., KIM, H.G. and LEE, D.H., 2017. Evaluating the potential of the extract of Perilla sp. as a natural insecticide for Bemisia tabaci (Hemiptera: Aleyrodidae) on sweet peppers. Entomological Research, vol. 47, no. 3, pp. 208-216. http://dx.doi.org/10.1111/1748-5967.12211.

KLIMES, P., BOROVANSKA, M., PLOWMAN, N. and LEPONCE, M., 2018. How common is trophobiosis with hoppers (Hemiptera: Auchenorrhyncha) inside ant nests (Hymenoptera: Formicidae)? Novel interactions from New Guinea and a worldwide overview. Myrmecological News, vol. 26, pp. 31-45.

KREBS, C.J., 1998 [viewed 2 May 2018]. Bray-Curtis cluster analysis [online]. Available from: http://biodiversity-pro.software. informer.com

LAMBSHEAD, P.J.D., PLATT, H.M. and SHAW, K.M., 1983. The detection of differences among assemblages of marine benthic species based on an assessment of dominance and diversity. Journal of Natural History, vol. 17, no. 6, pp. 859-874. http://dx.doi. org/10.1080/00222938300770671.

LE GOFF, G., MAILLEUX, A.C., DETRAIN, C., DENEUBOURG, J.L., CLOTUCHE, G. and HANCE, T., 2009. Spatial distribution and inbreeding in Tetranychus urticae. Comptes Rendus Biologies, vol. 332, no. 10, pp. 927-933. http://dx. doi.org/10.1016/j. crvi.2009.06.002. PMid:19819413.

LEITE, G.L.D., PIMENTA, M., FERNANDES, P.L., VELOSO, R.V.S. and MARTINS, E.R., 2008. Fatores que afetam artrópodes associados a cinco acessos de ginseng-brasileiro (Pfaffia glomerata) em Montes Claros, Estado de Minas Gerais. Acta Scientiarum. Agronomy, vol. 30, no. 1, pp. 7-11. http://dx.doi.org/10.4025/ actasciagron.v30i1.1110.

LEITE, G.L.D., VELOSO, R.V.S., SILVA, F.W.S., GUANABENS, R.E.M. and FERNANDES, G.W., 2009. Within tree distribution of a gallinducing Eurytoma (Hymenoptera, Eurytomidae) on Caryocar brasiliense (Caryocaraceae). Brazilian Journal of Biology = Revista Brasileira de Biologia, vol. 53, no. 4, pp. 643-648. http://dx.doi. org/10.1590/S0085-56262009000400015.

LEITE, G.L.D., VELOSO, R.V.S., ZANUNCIO, J.C., ALMEIDA, C.I.M., FERREIRA, P.S.F., FERNANDES, G.W. and SOARES, M.A., 2012. Habitat complexity and Caryocar brasiliense herbivores (Insecta: Arachnida: Araneae). The Florida Entomologist, vol. 95, no. 4, pp. 819-830. http://dx.doi.org/10.1653/024.095.0402.

LEITE, G.L.D., VELOSO, R.V.S., ZANUNCIO, J.C., ALONSO, J., FERREIRA, P.S.F., ALMEIDA, C.L.M., FERNANDES, G.W. and SERRÃO, J.E., 2016. Diversity of Hemiptera (Arthropoda: Insecta) and their natural enemies on Caryocar brasiliense (Malpighiales: Caryocaraceae) trees in the Brazilian Cerrado. The Florida Entomologist, vol. 99, no. 2, pp. 239-247. http:// dx.doi.org/10.1653/024.099.0213.
LEITE, G.L.D., VELOSO, R.V.S., ZANUNCIO, J.C., AZEVEDO, A.M., SILVA, J.L., WILCKEN, C.F. and SOARES, M.A., 2017. Architectural diversity and galling insects on Caryocar brasiliense trees. Scientific Reports, vol. 7, no. 1, pp. 16677. http://dx. doi.org/10.1038/ s41598-017-16954-6.

LEMES, P.G., ANJOS, N. and JORGE, I.R., 2013. Bioecology of Oncideres ocularis Thomson (Coleoptera: Cerambycidae) on Acacia mangium Willd. (Fabaceae). Journal of the Kansas Entomological Society, vol. 86, no. 4, pp. 307-317. http://dx.doi. org/10.2317/ JKES121121.1.

MCGILL, B.J., ENQUIST, B.J., WEIHER, E. and WESTOBY, M., 2006. Rebuilding community ecology from functional traits. Trends in Ecology \& Evolution, vol. 21, no. 4, pp. 178-185. http://dx.doi. org/10.1016/j.tree.2006.02.002. PMid:16701083.

MENEZES, C.W.G., BERTOLUCCI, S.K.V., PINTO, J.E.B.P., CARVALHO, G.A. and SOARES, M.A., 2013. First record of Aethalion reticulatum (Hemiptera: Aethalionidae) in Vernonia condensata (Asteraceae), a medicinal plant from Brazil. Phytoparasitica, vol. 41, no. 5, pp. 611-613. http://dx.doi.org/10.1007/s12600-013-0322-0.

MONTEIRO, L.B., TOMBA, J.A.S., NISHIMURA, G., MONTEIRO, R.S., FOELKEL, E. and LAVIGNE, C., 2019. Faunistic analyses of fruit fly species (Diptera: Tephritidae) in orchards surrounded by Atlantic Forest fragments in the metropolitan region of Curitiba, Paraná state, Brazil. Brazilian Journal of Biology $=$ Revista Brasileira de Biologia, vol. 79, no. 3, pp. 395-403. http://dx.doi. org/10.1590/1519-6984.178458. PMid:30231137.

NARANJO, S. and FLINT, H.M., 1995. Spatial distribution of adult of adult Bemisia tabaci (Homoptera; Aleyrodidae) in cotton and development of fixed precision sequential sampling plans for estimating population density. Environmental Entomology, vol. 24, no. 2, pp. 261-270. http://dx.doi.org/10.1093/ee/24.2.261.

NICKELE, M.A., OLIVEIRA, E.B., REIS FILHO, W., IEDE, E.T. and RIBEIRO, R.D., 2010. Spatial distribution of nests of Acromyrmex crassispinus (Forel) (Hymenoptera: Formicidae) in Pinus taeda plantations. Neotropical Entomology, vol. 39, no. 6, pp. 862-872. http://dx.doi.org/10.1590/S1519-566X2010000600003.

NOVGORODOVA, T.A., 2015. Organization of honeydew collection by foragers of different species of ants (Hymenoptera: Formicidae). European Journal of Entomology, vol. 112, no. 4, pp. 688-697. http://dx.doi.org/10.14411/ eje.2015.077.

PARREIRA, D.S., ZANUNCIO, J.C., MIELKE, O.H.H., WILCKEN, C.F., SERRÃO, J.E. and ZANUNCIO, T.V., 2014. Periphoba hircia (Lepidoptera: Saturniidae) defoliating plants of Acacia mangium in the State of Roraima, Brazil. The Florida Entomologist, vol. 97, no. 1, pp. 325-328. http://dx.doi.org/10.1653/024.097.0153.

PAULA, R.R., JEAN-PIERRE, B., GONÇALVES, J.L.M., TRIVELIN, P.C.O., BALIEIRO, F.C., NOUVELLON, Y., OLIVEIRA, J.C., DEUS JÚNIOR, J.C., BORDRON, B. and LACLAU, J.P., 2018. Nitrogen fixation rate of Acacia mangium Wild at mid rotation in Brazil is higher in mixed plantations with Eucalyptus grandis Hill ex Maiden than in monocultures. Annals of Forest Science, vol. 75, no. 14, pp. 1-14. http://dx.doi.org/10.1007/s13595-018-0695-9.

PEETERS, P.J., 2002. Correlations between leaf structural traits and the densities of herbivorous insect guilds. Journal of The Linnean Society, vol. 77, no. 1, pp. 43-65. http://dx.doi.org/10.1046/j.10958312.2002.00091.x.

PIRES, E.M., SILVA, L.C., BATTIROLA, L.D., NOGUEIRA, R.M., BARRETO, M.R. and CORASSA, J.N., 2014. Triplaris americana L. (Polygonaceae), a new host plant for Aethalion reticulatum (Linnaeus, 1767) (Hemiptera: aethalionidae). Brazilian Archives of Biology and Technology, vol. 58, no. 1, pp. 31-33. http://dx.doi. org/10.1590/S1516-89132014000 39. 
PRÜM, B., SEIDEL, R., BOHN, H.F. and SPECK, T., 2012. Plant surfaces with cuticular folds are slippery for beetles. Journal of the Royal Society, Interface, vol. 9, no. 66, pp. 127-135. http://dx.doi. org/10.1098/rsif.2011.0202. PMid:216 42366.

RIVAULT, C., CLOAREC, A. and SRENG, L., 1998. Cuticular extracts inducing aggregation in the German cockroach, Blattella germanica (L.). Journal of Insect Physiology, vol. 44, no. 10, pp. 909-918. http://dx.doi.org/10.1016/S0022-1910(98)00062-6. PMid:12770427.

SALERNO, G., REBORA, M., GORB, E. and GORB, S., 2018. Attachment ability of the polyphagous bug Nezara viridula (Heteroptera: Pentatomidae) to different host plant surfaces. Scientific Reports, vol. 8, no. 1, pp. 10975. http://dx.doi.org/ 10.1038/s41598-01829175-2. PMid:30030448.

SANCHEZ, J.A., LÓPEZ-GALLEGO, E. and LA-SPINA, M., 2020. The impact of ant mutualistic and antagonistic interactions on the population dynamics of sap-sucking hemipterans in pear orchards. Pest Management Science, vol. 76, no. 4, pp. 1422-1434. http://dx.doi.org/10.1002/ps.5655. PMid:31628776.

SANTOS, A.J.N., BROGLIO, S.M.F., DIAS-PINI, N.S., SOUZA, L.A. and BARBOSA, T.J.A., 2012. Stingless bees damage broccoli inflorescences when collecting fibers for nest building. Scientia Agrícola, vol. 69, no. 4, pp. 281-283. http://dx.doi. org/10.1590/ S0103-90162012000400008.

SANTOS, C.F., HALINSKI, R., SANTOS, P.D.S., ALMEIDA, E.A.B. and BLOCHTEIN, B., 2019. Looking beyond the flowers: associations of stingless bees with sap-sucking insects. Naturwissenschaften, vol. 106, no. 3-4, pp. 12. http://dx.doi.org/10. 1007/s00114019-1608-y.

SERRA, B.D. and CAMPOS, L.A., 2010. Polinização entomófila de abobrinha, Cucurbita moschata (Cucurbitaceae). Neotropical Entomology, vol. 39, no. 2, pp. 153-159. http://dx.doi.org/10.1590/ S1519-566X2010000200002. PMid:20498949.

SILVA, D.P. and FERNANDES, J.A.M., 2016. New evidences supporting trophobiosis between populations of Edessa rufomarginata (Heteroptera: Pentatomidae) and Camponotus (Hymenoptera: Formicidae) ants. Brazilian Journal of Biology = Revista Brasileira de Biologia, vol. 60, no. 2, pp. 166-170. http://dx.doi.org/10.1016/j. rbe.2016.02.002.

SILVA, F.W.S., LEITE, G.L.D., GUANABENS, R.E.M., SAMPAIO, R.A., GUSMÃO, C.A.G., SERRÃO, J.E. and ZANUNCIO, J.C., 2015. Seasonal abundance and diversity of arthropods on Acacia mangium (Fabales: Fabaceae) trees as windbreaks in the Cerrado. The
Florida Entomologist, vol. 98, no. 1, pp. 170-174. http://dx.doi. org/10.1653/024.098.0129.

SILVA, J.L., LEITE, G.L.D., TAVARES, W.S., SILVA, F.W.S., SAMPAIO, R.A., AZEVEDO, A.M., SERRÃO, J.E. and ZANUNCIO, J.C., 2020. Diversity of arthropods on Acacia mangium (Fabaceae) and production of this plant with dehydrated sewage sludge in degraded area. Royal Society Open Science, vol. 7, pp. 191196. http://dx.doi.org/10.1098/rsos.191196. PMid:32257306.

SILVEIRA, T.M.T., RASEIRA, M.C.B., NAVA, D.E. and COUTO, M., 2010. Influência do dano da abelha-irapuá em flores de mirtileiro sobre a frutificação efetiva e as frutas produzidas. Revista Brasileira de Fruticultura, vol. 32, no. 1, pp. 303-307. http:// dx.doi.org/10.1590/S0100-29452010005000034.

SOTI, V., LELONG, C., GOEBEL, F.R. and BRÉVAULT, T., 2018. Designing a field sampling plan for landscape-pest ecological studies using VHR optical imagery. International Journal of Applied Earth Observation and Geoinformation, vol. 72, pp. 26-33. http:// dx.doi.org/10.1016/j.jag.2018.05.016.

TONG, H., AO, Y., LI, Z., WANG, Y. and JIANG, M., 2019. Invasion biology of the cotton mealybug, Phenacoccus solenopsis Tinsley: current knowledge and future directions. Journal of Integrative Agriculture, vol. 18, no. 4, pp. 758-770. http://dx.doi.org/10.1016/ S2095-3119(18)61972-0.

UNIVERSIDADE FEDERAL DE VIÇOSA - UFV, 2007 [viewed 30 June 2018]. Sistema para Análises Estatísticas e Genéticas (SAEG). Version 9.1 [online]. Available from: http://arquivo.ufv.br/saeg/

VENTURINO, E., ISAIA, M., BONA, F., CHATTERJEE, S. and BADINO, G., 2008. Biological controls of intensive agroecosystems: wanderer spiders in the Langa astigiana. Ecological Complexity, vol. 5, no. 2, pp. 157-164. http://dx.doi. org/10.1016/j.ecocom.2007.10.003.

WANG, F., ZHU, W., ZOU, B., NEHER, D.A., FU, S., XIA, H. and LI, Z., 2013. Seedling growth and soil nutrient availability in exotic and native tree species: implications for afforestation in southern China. Plant and Soil, vol. 364, no. 1-2, pp. 207-218. http://dx.doi.org/10.1007/s11104-012-1353-x.

WILCOXON, F., 1945. Individual comparisons by ranking methods. Biometrics Bulletin, vol. 1, no. 6, pp. 80-83. http://dx.doi. org/10.2307/3001968.

ZANUNCIO, A.J.V., SERRÃO, J.E., PEREIRA, A.I.A., SOARES, M.A., WILCKEN, C.F., LEITE, G.L.D. and ZANUNCIO, J.C., 2015. Aethalion reticulatum (Hemiptera: Aethalionidae) feeding on Erythrina speciosa (Fabales: Fabaceae): first record of its host plant and damage characteristics. The Florida Entomologist, vol. 98, no. 1, pp. 175-177. http://dx.doi.org/10.1653/024. 098.0130. 


\section{Supplementary Material}

Supplementary material accompanies this paper.

Supplementary material I. Number of arthropod species per leaf (mean \pm SE) collected on Acacia mangium (Fabales: Fabaceae) sapling used to calculate the ecological indexes which were non-significant ( $p$-value >0.05)

This material is available as part of the online article from https://www.scielo.br/j/bjb 